\title{
ACTUL ADMINISTRATIV ȘI ACTUL ADMINISTRAȚIEI
}

\author{
DOl:10.24193/SUBBiur.62(2017).1.2 \\ Published Online: 2017-03-15 \\ Published Print: 2017-03-30
}

\section{Oana Bianca CĂBULEA (GLIGAN)*}

\begin{abstract}
Administrative act and act of the administration. Even if at first sight the joining of the two concepts reminds us by a synonym of terms or a homonymy, we showed that in reality these two concepts are different in their substance. The category of administrative acts is much broader and includes the category of acts of administration. In order to clarify the distinction, we analyzed the notions of administrative act and act of the administration and presented several administrative acts, which are not issued by government bodies.

We mainly researched the acts of judges, taking into account the concept of judicial act and we noticed that most of the documents issued in the work of justice are not jurisdictional, but are administrative acts issued by the judiciary. Another point of interest in our study was the public notary documents, which we have divided into three distinct categories for more accurate identification of their legal nature. We finally remembered the category of administrative acts that comprise civil rights in their content, such as title deeds and acts of civil status.

Our conclusion was that the distinction between administrative acts and other acts issued by a public power can not have as a starting point neither the type of the issuing body, nor the legal procedure for contesting it. The criterion that we have identified and which we appreciated suitable is the form of activity that will achieve through the act.
\end{abstract}

Keywords: administrative act, act of the administration, judicial act, imperium, notary public documents

Cuvinte cheie: act administrativ, act al administrației, act jurisdicțional, imperium, acte notariale

La o primă vedere, alăturarea noțiunilor menționate ne duce cu gândul fie la o sinonimie de termeni, fie la o omonimie. În realitate, vom vedea că aceste două concepte sunt diferite în substanța lor, categoria actului administrativ fiind una mult mai largă și care include categoria actului administrației (1). Pentru o înțelegere mai limpede vom proceda la analiza anumitor tipuri de acte administrative, care nu sunt și acte ale administrație (2). 


\section{Noțiune}

Etimologic, termenul administrație provine din limba latină, fiind format din prepoziția „ad” care se traduce prin „la” sau „către” și substantivul „minister”, cu semnificația de „servitor”, „,îngrijitor”, ,ajutător”. Aceste elemente au format cuvântul „administer" care prezintă o dublă conotație, atât aceea de „ajutor al cuiva”, de "executant" ori de „slujitor”, cât și sensul figurativ de „unealtă" sau de „instrument"1.

Administrația publică este definită în doctrină ca fiind ansamblul activităților Președintelui României, Guvernului, autorităților administrative autonome locale și, după caz, structurile subordonate acestora prin care, în regim de putere publică, se aduc la îndeplinire legile sau, în limitele legii, se prestează servicii publice ${ }^{2}$. Administrația publică este o activitate complexă prin care autoritățile publice urmăresc să asigure satisfacerea interesului general al societății, inclusiv prin folosirea, în caz de necesitate, a prerogativelor de putere publică.

Sfera administrației publice se delimitează prin raportare la principiul separației puterilor în stat sau, mai precis, prin prisma ideii de colaborare între acestea, fiind reliefată ca o activitate a statului sau a tuturor titularilor de putere publică, care nu este legiferare și nici justiție ${ }^{3}$. Astfel, doctrina tratează administrația ca pe o putere autonomă a statului, alături de puterea legislativă și cea judecătorească. Aceasta este privită în contrast cu justiția, a cărei menire este aceea de a face aplicarea dreptului în cazuri determinate și cu funcția legislativă, care are datoria de a legifera. Administrația, pe de altă parte, are datoria de a modela societatea în cadrul legilor și pe baza dreptului.

Structura administrativă și actele administrației sunt aspecte ce țin de instituțiile de drept constituțional, motiv pentru care acestea trebuie analizate prin prisma sistemului suprem de care aparțin. În lucrarea de față ne raportăm la înfățișarea actelor administrative realizată conform Constituției din anul 1991, iar discuția noastră are sens în această constituire constituțională. Legiuitorul constituant a atribuit administrației publice capitolul V al Constituției României, reglementând în cadrul primei secțiuni administrația publică centrală de specialitate, iar în cea de-a doua, administrația publică locală.

Pe de altă parte, în cuprinsul art. 2 alin. 1 lit. b) din Legea nr. 554/2004 a contenciosului administrativ ${ }^{4}$, legiuitorul a definit noțiunea de autoritate publică, arătând că aceasta este reprezentată de orice organ de stat sau al unităților administrativteritoriale care acționează, în regim de putere publică, pentru satisfacerea unui interes public, fiind asimilate și persoanele juridice de drept privat care, potrivit legii, au obținut statut de utilitate publică sau sunt autorizate să presteze un serviciu public.

Formele concrete prin care autoritățile administrației publice organizează executarea și execută legea sunt actele administrative, faptele material-juridice, operațiunile tehnicomateriale și actele politice. Cu toate că autoritățile administrative sunt cele învestite, în principal, cu puterea de a emite, în mod unilateral, acte administrative cu caracter obligatoriu și executoriu, vom vedea că acestea nu sunt singurele organe care au dreptul de a adopta asemenea acte. Chiar definiția dată de legiuitor autorității publice ne sugerează că formele concrete de manifestare a puterii publice sunt efectuate uneori și de autorități aparținând puterii legislative sau de autorități aparținând puterii judecătorești, precum și de către societăți comerciale, regii autonome, instituții publice și asociații ori fundații private. 
Actele administrative sunt, în primul rând, o categorie de acte juridice, fiind caracterizate așadar prin faptul că reprezintă manifestări de voință făcute cu scopul de a produce anumite efecte juridice, a căror realizare este garantată prin forța de constrângere a statului, în condițiile prevăzute de normele juridice în vigoare ${ }^{5}$. Definiția legală actuală cuprinsă în art. 2 alin. 1 lit. c) din Legea contenciosului administrativ nr. 554/2004 ne spune că actul administrativ este actul unilateral cu caracter individual sau normativ, emis de o autoritate publică în vederea executării legii, care dă naștere, modifică sau stinge raporturi juridice; sunt asimilate actelor administrative, în sensul prezentei legi, și contractele încheiate de autoritățile publice care au ca obiect: punerea în valoare a bunurilor proprietate publică; executarea lucrărilor de interes public; prestarea serviciilor publice sau achizițiile publice.

Doctrina juridică ${ }^{6}$ susține, de regulă, punctul de vedere conform căruia, în activitatea de aplicare a dreptului, organele administrației publice emit acte administrative, iar instanțele de judecată emit acte jurisdicționale. Între aceste două tipuri de acte se situează actele administrativ jurisdicționale, o categorie hibridă aparținând organelor administrației publice care sunt abilitate să desfășoare și activitate jurisdicțională. În studiul de față vom prezenta lucrurile dintr-un alt unghi, cu scopul de a demonstra că există un criteriu de distincție mai eficient decât cel al calității organului emitent al unui act, și anume finalitatea actului.

Începem prin a arăta că puterea publică nu este un atribut exclusiv al administrației, ci este specifică tuturor autorităților publice din sfera celor trei puteri de stat, fiind dedusă din legea supremă. În democrațiile moderne, puterea de stat este reprezentată de un sistem de organe competente să exercite funcțiile legislativă, executivă și judecătorească. Așa fiind, calitatea subiectului de drept care emite actul nu reprezintă un criteriu pentru calificarea acestuia. Actele care provin de la alte organe de stat care dețin putere publică, dar nu au competența obișnuită de a emite acte administrative, respectiv de la celelalte puteri tradiționale, au fost denumite în doctrină acte administrative-mijloc ${ }^{7}$. Explicația rezidă în împrejurarea că aceste autorități, prin desfășurarea activității lor, urmăresc un alt scop, dar în realizarea acestuia emit uneori, cu titlu excepțional, acte administrative.

Luând în considerare subiecții de drept care au abilitatea de a emite acte administrative, constatăm că, într-adevăr, așa cum am arătat și mai sus, categoria actelor administrative nu se suprapune și nu poate fi redusă la categoria actelor de administrație. Acestea din urmă fac parte din mulțimea mai generoasă a primelor, dar se individualizează prin calitatea autorului lor, respectiv un organ aparținând administrației publice. Sensurile astfel deslușite le vom avea și noi în vedere pe parcursul lucrării.

\section{Analiza anumitor tipuri de acte administrative}

Dintre actele administrative ne-am concentrat atenția asupra actelor emise de organele judiciare (a) și a actelor notariale (b) deoarece acestea sunt foarte uzuale și permit reliefarea unor aspecte relevante pentru studiul de față. În cadrul secțiunii referitoare la actele emise de organele judiciare vom aborda noțiunile de act procesual și act de procedură, act jurisdicțional, iar apoi vom trata natura juridică a anumitor hotărâri judecătorești și a unor acte emise de Curtea Constituțională. De asemenea, am realizat o trecere în revistă a unor acte administrative care conțin drepturi civile (c). 


\section{a. Actul de jurisdicție și actul administrativ al instanței}

Una dintre puterile de stat care emite acte administrative este cea judecătorească, iar cea mai vizibilă parte a acesteia o constituie instanțele de judecată. Acestea din urmă, în vederea îndeplinirii misiunii lor, apelează la o multitudine de acte emise în regim de putere, care însă nu pot fi catalogate ca acte de administrație. De pildă, ordinul de serviciu prin care președintele unei instanțe desemnează judecătorii care urmează să îndeplinească, potrivit legii, și alte atribuții decât cele privind activitatea de judecată și stabilește atribuțiile pe care urmează să le îndeplinească aceștia este un astfel de act. În același fel se concretizează și celelalte prerogative administrative ale președintelui instanței ${ }^{8}$ sau ale colegiului de conducere.

Am observat că judecătorii sunt învestiți prin lege cu dreptul de a emite acte de autoritate obligatorii și executorii chiar și în alte situații, iar nu doar atunci când exercită atribuții de organizare a instanței. Un exemplu în acest sens poate fi încheierea prin care președintele completului de judecată aplică o amendă judiciară. Mai mult decât atât, analizând atent actele instanței de judecată, vom încerca să demonstrăm că majoritatea dintre aceste sunt acte administrative, iar nu jurisdicționale.

\section{Acte procesuale și acte de procedură}

În doctrină și în practică, există tendința firească de a se considera că organele judiciare emit acte judiciare care sunt de procedură. În materia dreptului procesual civil, activitatea jurisdicțională cuprinde o serie de acte care provin de la toți participanții din cauză și care sunt reglementate de legiuitor în ceea de privește conținutul și modalitatea de aducere la îndeplinire. Aceste reguli edictate pentru a organiza desfășurarea unui proces sunt denumite de doctrină forme procedurale ${ }^{9}$. Ele vizează toate etapele itinerariului judiciar, precum chemarea în judecată, verificarea competenței, administrarea probelor, dezbaterea și pronunțarea hotărârii, în fiecare ciclu procesual. Aceste forme urmăresc asigurarea organizării unui cadru în conformitate cu normele și principiile dreptului civil pentru tranșarea de către instanță a litigiului în mod corect și temeinic.

Unii autori au susținut că există o corelație între formele și actele de procedură, în sensul că forma este ceea ce legea prescrie, iar actul de procedură reprezintă forma adusă la îndeplinire ${ }^{10}$. în acest sens, citarea ar constitui forma procedurală pentru chemarea în fața instanței a unei părți și asigurarea deopotrivă a dreptului la apărare și a contradictorialității, iar citația ar reprezenta actul de procedură prin care se îndeplinesc aceste obiective. Cu toate acestea, s-a apreciat ${ }^{11}$ că uneori noțiunile de formă și act de procedură se utilizează împreună în expresia forma actelor de procedură, pentru a se reliefa prezența unor condiții extrinseci necesare valabilității unor acte de procedură.

În dreptul procesual civil se înglobează în sintagma de operațiune juridică atât operațiunea juridică propriu-zisă, cât și actul care o constată, indiferent dacă emană de la instanța de judecată, una dintre părți sau un alt participant la proces. Astfel, act de procedură constituie orice manifestare de voință și orice operație juridică făcută în cadrul procesului civil de către instanța de judecată, părți sau ceilalți participanți la proces, în 
legătură cu exercitarea drepturilor sau îndeplinirea obligațiilor lor procesuale, respectiv în vederea producerii unor efecte juridice în plan procesual.

Conform doctrinei procesual penale, actul procesual reprezintă o condiție de aplicabilitate a actului procedural, iar acesta din urmă constituie o condiție pentru valabilitatea și recunoașterea procesuală a actului procesual și ambele categorii sunt încorporate în înscrisurile denumite documente procedurale, care fac dovada îndeplinirii actelor și asigură construirea dosarului penal, unde manifestările de voință ale tuturor participanților la proces trebuie să fie riguroase și concise ${ }^{12}$. În concluzie, în dreptul procesual penal, actele și măsurile procesuale sunt acte de dispoziție, care sunt puse în executare cu ajutorul actelor procedurale.

Noi considerăm că această teorie nu este exactă, lucrurile fiind mult mai nuanțate. Plecând de la noțiuni de ordin terminologic, constatăm, în primul rând, că termenul jurisdicție desemnează puterea, competența unui judecător sau a unei instanțe de a judeca. Noțiunea provine din latinul jurisdictio care înseamnă a zice dreptul, a tranșa ceva. Aceasta se identifică așadar cu funcția esențială a judecătorului, aceea de a spune dreptul în rezolvarea litigiilor cu care este învestit. Considerăm că actele juridice propriu-zise sunt emise de puterea judecătorească exclusiv atunci când magistratul își îndeplinește menirea, își exercită imperium-ul cu privire la tranșarea unei probleme.

\section{Actul jurisdicțional}

Departe de a beneficia de o abordare unitară, noțiunea de act jurisdicțional constituie subiect de dezbatere în doctrina juridică, nu doar din perspectiva definirii sale, ci și în privința criteriilor de distincție. În funcție de calitatea autorului unui astfel de act, caracterizarea sa a fost diferită în dreptul privat față de dreptul public.

În încercarea de a identifica trăsăturile actul jurisdicțional, un autor ${ }^{13}$ a apelat la trei criterii de individualizare, respectiv formal, funcțional și organic. Primul dintre acestea vizează realizarea unei delimitări a actului jurisdicțional față de actul normativ, precum și față de cel administrativ. Astfel, hotărârea judecătorească a fost diferențiată de actul normativ prin sfera efectelor sale, restrânsă la părțile din proces.

În plus, s-a mai susținut că spre deosebire de actul administrativ, normativ sau individual, care se emite independent de existența unui conflict, hotărârea presupune soluționarea a posteriori a unui litigiu. Teoria menționată a fost criticată arătându-se, pe de o parte, că se întâlnesc situații în care judecătorul pronunță hotărâri menite să prevină litigii, iar, pe de altă parte, unele acte normative sunt edictate tocmai pentru a înlătura existența unor conflicte ${ }^{14}$. Tot în cadrul analizei criteriului formal, au fost evidențiate și alte particularități, precum necesitatea învestirii judecătorului în scopul emiterii unui act jurisdicțional, caracterul solemn și obligativitatea motivării acestui act, precum și faptul că procesul trebuie să respecte o serie de formalități procesuale și procedurale.

Criteriul funcțional subliniază faptul că judecătorul se supune legii și că rolul actului jurisdicțional este acela de a spune dreptul în spețe concrete. Într-o altă perspectivă s-a arătat însă că această trăsătură nu este una specifică actului jurisdicțional deoarece și organele administrative aplică dreptul la situații de fapt și se supun legii atunci când emit acte $^{15}$. Nici argumentul referitor la puterea lucrului judecat care este atașată actului 
jurisdicțional nu a fost determinant, din moment ce natura unui astfel de act nu poate fi caracterizată prin efectele sale ${ }^{16}$.

Cel din urmă criteriu abordat de autor, cel organic, se fundamentează pe principiul independenței care guvernează activitatea judecătorilor, pe ideea conform căreia actul jurisdicțional este emis în urma unei deliberări, de un organ colegial, luând totodată în considerare faptul că actul jurisdicțional este supus căilor de atac și poate fi reformat de instanțele de control. Insuficiența acestui criteriu s-a dovedit prin faptul că este prea general pentru a putea trasa cu precizie limitele și trăsăturile actului jurisdicțional.

Un alt punct de vedere ${ }^{17}$ exprimat în doctrina de specialitate a prezentat o clasificare distinctă, utilizând criteriile extrinsec, intrinsec și eclectic. Conform celui dintâi, actul jurisdicțional ar fi definit de calitatea autorului emitent al actului, pe când cel intrinsec pornește de la ideea că ceea ce importă este mai degrabă existența unui conflict și efectul actului concretizat în puterea de lucru judecat. Ambele concepții au prezentat dezavantaje, atâta timp cât disputa nu a fost tranșată, fiind deviată fie spre definirea autorului actului, fie spre explicarea numeroaselor excepții remarcate. S-a ajuns astfel la criteriul eclectic, care însumează mai multe cerințe necesare pentru a determina prezența unui act jurisdicțional, cum ar fi calitatea autorului, organ de jurisdicție, existența unui conflict sau incidența unei proceduri speciale.

Aceste caracteristici ale actului jurisdicțional, comune în marea parte a opiniilor exprimate, au fost categorisite și în criterii formale sau materiale. În clasa celor formale au fost incluse cele referitoare la specificul autorității emitente, considerându-se că actul jurisdicțional este cel care provine de la un organ jurisdicțional, la procedura specială de adoptare și la independența judecătorului. De cealaltă parte au fost situate criteriile care au luat în calcul existența unui litigiu, ca element distinctiv al actului jurisdicțional, structura acestui act compus dintr-o pretenție, o constatare și o hotărâre, precum și finalitatea actuluii ${ }^{18}$. Alături de acești autori, considerăm și noi că elementul specific actului jurisdicțional, care îl distinge de celelalte acte de putere publică, este reprezentat de scopul acestuia, respectiv tranșarea unei chestiuni juridice, ca urmare a aplicării regulilor de drept incidente situației de fapt deduse judecății.

Prin raportare la aspectele expuse, considerăm că actul jurisdicțional este cel prin care un organ abilitat, respectiv o instanță judecătorească sau o altă autoritate cu activitate jurisdicțională, în exercitarea atribuțiilor care îi sunt conferite prin lege, soluționează o problemă juridică, răspunzând pretențiilor și apărărilor părților formulate în cauză.

Așa fiind, din întreaga activitate a unui organ jurisdicțional, numai lucrurile esențiale pot fi catalogate drept judiciare și doar chestiunea de tranșare a unei probleme de drept prin aplicarea sa la o situație de fapt concretă reprezintă un element juridic. Pentru a ne afla în prezența unui act jurisdicțional, pe lângă criteriul referitor la calitatea organului emitent, care s-a dovedit insuficient, este necesar să constatăm întrunirea a două condiții esențiale: actul respectiv să fie rezultatul unui raționament prin care să fie mai întâi stabilită norma de drept incidentă în cauză, iar apoi aceasta să fie aplicată în concret cauzei cu care este învestit organului jurisdicțional.

Menționăm că, deși a fost vehiculată și cerința existenței unui litigiu sau a unui conflict ${ }^{19}$, acest aspect nu poate fi considerat un atribut specific actului jurisdicțional. Este 
adevărat că cea mai mare parte a acestor acte intervin la finalul unei proceduri contencioase, însă concluzia că toate actele jurisdicționale ar fi condiționate de tranșarea unui litigiu este falsă. Chiar dacă prin procedura grațioasă se tinde la soluționarea unor cereri pentru a căror dezlegare nu este necesară stabilirea unui drept potrivnic față de o altă persoană, nu se poate nega cu desăvârșire caracterul jurisdicțional al hotărârilor pronunțare într-o astfel de procedură. Nici opinia potrivit căreia aceste acte ar fi mixte, situate între actele administrative și cele jurisdicționale nu este adecvată, fiind posibilă și chiar necesară o calificare certă.

Considerăm că și în procedura necontencioasă putem să întâlnim atât acte jurisdicționale, cât și acte administrative, criteriul de distincție fiind același. Astfel, dacă activitatea judecătorului nu se rezumă la verificarea unor condiții legale, ci presupune analiza și aprecierea normelor de drept incidente prin raportare la situația de fapt, realizând astfel judecata, atunci ne aflăm în prezența unui act jurisdicțional. Cu titlu de exemplu, amintim hotărârea prin care instanța soluționează o plângere împotriva încheierii de carte funciară. Prin urmare, caracterul grațios al procedurii nu presupune per se doar acte non jurisdicționale și nici reversul nu este valabil.

Astfel cum a arătat un autor ${ }^{20}$, în funcție de caracterul lor, actele de procedură se împart în acte jurisdicționale, respectiv cele pe care judecătorul le îndeplinește în exercițiul funcțiunii sale jurisdicționale, care privesc în mod direct soluționarea chestiunii deduse judecății și acte procesuale administrative (acte funcționale ori acte judiciare de administrație, denumite în legislația franceză măsuri de administrare judiciară). Spre deosebire de viziunea acestuia conform căreia actele jurisdicționale sunt majoritare, noi credem, din contră, că balanța este înclinată în favoarea actelor administrative.

\section{Hotărârile judecătorești}

Conform definiției conturate în doctrină, hotărârea judecătorească este actul de dispoziție al instanței de judecată cu privire la pretențiile pe care părțile le-au dedus judecății, fiind deci actul final al judecății ${ }^{21}$. Hotărârea reprezintă scopul urmărit prin declanșarea procesului, rațiunea lui de a fi, având în vedere că este menită să tranșeze conflictul dintre părți și să înlocuiască părerea, de regulă diferită, a părților cu părerea judecătorului, care are însă autoritatea prevăzută de lege și, la nevoie, poate fi impusă silit, cu ajutorul forței de constrângere a statului ${ }^{22}$.

Actul final al procesului constituie opera judecătorului, fiind un comandament izvorât din imperium, acea parte din puterea statală al cărei deținător este judecătorul, care se îmbină cu forța publică pentru a asigura executarea silită a hotărârii în cazul în care cel ce a pierdut procesul nu execută de bunăvoie. Totodată, hotărârea este un raționament care se obține ca urmare a unei dezbateri, iar judecătorul dispune în conformitate cu legea, astfel că puterea sa nu este voință pură, ci exprimă dreptul și îl impune ${ }^{23}$.

Putem oare însă să spunem că toate hotărârile judecătorești sunt acte jurisdicționale? Credem că nu. Aceasta deoarece legiuitorul a reglementat și anumite tipuri de hotărâri care nu presupun tranșarea propriu-zisă de către instanță a unei chestiuni juridice și aplicarea sa unei spețe determinate. Intră în această categorie, spre exemplu, hotărârile de expedient, cele prin care se ia act de renunțarea la judecată sau la drept, cele prin care se 
constată perimarea cererii ori încheierile definitive de închidere a dosarului în materia ordonanței de plată.

În conformitate cu prevederile art. 438 alin. 1 C.pr.civ., părțile se pot înfățișa oricând în cursul judecății, chiar fără să fi fost citate, pentru a cere să se dea o hotărâre care să consfințească tranzacția lor. Potrivit art. 439 C.pr.civ. tranzacția părților va fi încheiată în formă scrisă și alcătuiește dispozitivul hotărârii astfel pronunțate. Așadar, în cadrul procesului civil, hotărârea ce cuprinde în dispozitiv însăși învoiala părților reprezintă un contract intervenit între părți prin mijlocirea justiției, așadar un contract judiciar, motiv pentru care s-a reținut în doctrină că acesta trebuie să respecte condițiile de fond și de formă pentru validitatea actelor juridice ${ }^{24}$. Faptul că un asemenea act este prezentat în fața instanței de judecată, care este datoare să pronunțe hotărârea de expedient dacă sunt întrunite cerințele necesare în acest scop, nu înseamnă nici că judecătorul ar deveni parte a actului, dar nici nu atribuie hotărârii date caracter jurisdicțional.

Dispozitivul unei hotărâri judecătorești trebuie să cuprindă soluția dată de instanță tuturor cererilor deduse judecății or, faptul că în cazul hotărârii de expedient dispozitivul este stabilit de părți, evidențiază aspectul că acest act nu respectă definiția hotărârii judecătorești. Chiar dacă instanța participă, într-adevăr, la perfectarea acestui contract judiciar, hotărârea de expedient nu poate fi considerată nicidecum ca un act de dispoziție al instanței. În cazul intervenirii unei tranzacții, soluționarea problemei juridice nu își are sursa în lumina și înțelepciunea judecătorului, acesta fiind doar un interlocutor al convenției părților.

Un argument suplimentar în acest sens este calea de atac acordată părților pentru a contesta o asemenea hotărâre. Conform prevederilor art. 440 C.pr.civ. hotărârea care consfințește tranzacția intervenită între părți va putea fi atacată, pentru motive procedurale, numai cu recurs la instanța ierarhică superioară. Împrejurarea că hotărârea nu este supusă și apelului este explicabilă tocmai prin aceea ca instanța ce pronunță hotărârea de expedient nu procedează la o judecare a fondului, limitându-se la a verifica dacă tranzacția îndeplinește condițiile prevăzute de lege și dacă este rezultatul voinței neviciate a părților.

De altfel, și calea de atac a recursului este limitată la motive procedurale, respectiv numai la acele critici referitoare la regulile de urmat în ceea ce privește darea hotărârii de expedient ${ }^{25}$. Celelalte motive de casare sunt inadmisibile, din moment ce hotărârea de expedient nu beneficiază de efectul pozitiv al puterii de lucru judecat, instanța nefăcând altceva decât să consfințească voința părților în cuprinsul hotărârii. Așa fiind, din moment ce instanța nu judecă litigiul într-o astfel de situație, credem că nu se poate susține în mod întemeiat că actul emis ar fi unul jurisdicțional. La fel stau lucrurile în privința tuturor hotărârilor prin care instanța ia act de exercitarea drepturilor de dispoziție ale părților, fără să procedeze la analiza pe fond a cererilor deduse judecății.

În ceea ce privește hotărârea judecătorească prin care se constată perimarea, apreciem că nici aceasta nu reprezintă un veritabil act jurisdicțional, dată fiind natura juridică a instituției. În literatura de specialitate s-a reținut că perimarea reprezintă nu doar o sancțiune procedurală pentru nerespectarea termenului stabilit de lege, ci și o prezumție de desistare a părților, dedusă din faptul lipsei de stăruință vreme îndelungată în judecată ${ }^{26}$. O altă definiție caracterizează perimarea ca pe un mod de stingere sau 
încetare a procesului în faza procesuală în care se găsește, din cauza rămânerii lui în nelucrare, din culpa părții, în tot timpul prevăzut de lege ${ }^{27}$.

Conform prevederilor art. 420 alin. 1 C.pr.civ., perimarea se constată fie din oficiu, fie la cererea părții interesate. Astfel, cu toate că perimarea intervine ope legis, producerea efectelor este condiționată de constatarea sa de către instanța de judecată, care se rezumă la verificarea îndeplinirii condițiilor necesar a fi îndeplinite pentru perimarea cererii (respectiv rămânerea cauzei în nelucrare timp de 6 luni, termenul de perimare să nu fi fost întrerupt sau suspendat pentru vreuna din cauzele indicate de art. 417 si 418 C.pr.civ., iar abandonarea cauzei în nelucrare să se datoreze culpei părții).

La fel ca în cazul hotărârii de expedient, nici hotărârea care constată perimarea nu este susceptibilă de a fi atacată cu apel, fiind supusă doar recursului, la instanța ierarhic superioară. Hotărârea judecătorească prin care se constată perimarea dezînvestește instanța și are ca efect stingerea procesului civil, ca urmare a lipsirii de eficacitate a tuturor actelor de procedură efectuate în respectiva cauză. Printr-un astfel de act nu are loc o rezolvare a fondului litigiului dedus judecății, fiind vorba despre un simplu act administrativ care marchează operațiunea de închidere a dosarului.

Atâta timp cât prin aceste acte nu se tranșează nicio chestiune juridică, judecătorul fiind încorsetat de voința părților sau de anumite condiții impuse de lege, apreciem că nu poate fi vorba, în aceste cazuri, despre operațiuni jurisdicționale. Activitatea judecătorului în asemenea ipoteze este una de natură mai degrabă administrativă, rolul său rezumându-se la emiterea unui act dictat de părți sau de legiuitor, în virtutea puterii cu care este învestit.

Cu atât mai puțin am putea să afirmăm în legătură cu rezoluțiile sau încheierile prin care, de pildă, se procedează la fixarea termenului de judecată, dispunerea unei comisii rogatorii, stabilirea unei cauțiuni, numirea unui curator sau a unui custode, că ar fi incluse în categoria actelor jurisdicționale. Pentru emiterea acestor acte, instanța nu își exercită atributul de judecată, ci urmează regulile stabilite de legiuitor. În materie de probațiune, chiar denumirea utilizată de legiuitor vine în sprijinul teoriei noastre, acesta folosind sintagma de administrare a probelor. Astfel, în etapa cercetării judecătorești, probele și mijloacele de probă sunt doar prezentate și gestionate în mod nemijlocit în fața instanței, în scopul stabilirii corecte și complete a stării de fapt, fără ca acestea să fie judecate în acest moment.

Aprecierea coroborată a probelor are loc doar în etapa deliberării, etapă în care judecătorul aplică dreptul la situația de fapt rezultată din probațiune. Acesta este momentul în care este exercitat în mod efectiv imperium-ul, activitatea de judecată presupunând transpunerea stării de fapt în drept și aplicarea normelor legale incidente pentru soluționarea litigiului. Funcția esențială de judecată se remarcă în etapa menționată și se finalizează cu emiterea actului jurisdicțional. Prin actele prealabile deliberării și soluționării cauzei, magistratul nu face altceva decât să își asigure cadrul necesar pentru parcurgerea itinerariului spre o hotărâre. Dacă am interpreta altfel, considerându-le acte de judecată, instanța s-ar desista după efectuarea fiecăruia dintre acestea, aspect în mod evident eronat. Față de aceste aspecte, considerăm că aproape toate actele emise de judecător sunt acte unilaterale administrative, emise în regim de putere publică, cu scopul de a organiza desfășurarea procesului sau operațiuni tehnico-materiale prin care se realizează punerea în executare a actelor. 


\section{Deciziile Curții Constituționale}

Mergând mai departe cu raționamentul nostru și analizând deciziile Curții Constituționale, care este situată la granița puterii judecătorești cu a celei executive, apreciem că o mare parte a actelor emise de această autoritate sunt administrative. Opinia majoritară în doctrină consideră Curtea Constituțională ca organ politico-jurisdicțional ${ }^{28}$. Fundamentul dimensiunii politice a naturii Curții Constituționale se află atât în modul de numire a membrilor săi, cât și în aspectul că atribuțiile Curții, chiar și cele care nu vizează controlul de constituționalitate a legilor, ordonanțelor Guvernului și regulamentelor Parlamentului, se referă în fond tot la aplicarea și respectarea Constituției, ca document politic și juridic.

Pentru a analiza caracterul actelor emise de Curtea Constituțională, trebuie să menționăm în prealabil atribuțiile acesteia, care determină și obiectul actelor specifice fiecăreia. Conform art. 146 din Constituția României, Curtea Constituțională are următoarele atribuții:

a) se pronunță asupra constituționalității legilor, înainte de promulgarea acestora, la sesizarea Președintelui României, a unuia dintre președinții celor două Camere, a Guvernului, a Înaltei Curți de Casație și Justiție, a Avocatului Poporului, a unui număr de cel puțin 50 de deputați sau de cel puțin 25 de senatori, precum și, din oficiu, asupra inițiativelor de revizuire a Constituției;

b) se pronunță asupra constituționalității tratatelor sau altor acorduri internaționale, la sesizarea unuia dintre președinții celor două Camere, a unui număr de cel puțin 50 de deputați sau de cel puțin 25 de senatori;

c) se pronunță asupra constituționalității regulamentelor Parlamentului, la sesizarea unuia dintre președinții celor două Camere, a unui grup parlamentar sau a unui număr de cel puțin 50 de deputați sau de cel puțin 25 de senatori;

d) hotărăște asupra excepțiilor de neconstituționalitate privind legile și ordonanțele, ridicate în fața instanțelor judecătorești sau de arbitraj comercial; excepția de neconstituționalitate poate fi ridicată și direct de Avocatul Poporului;

e) soluționează conflictele juridice de natură constituțională dintre autoritățile publice, la cererea Președintelui României, a unuia dintre președinții celor două Camere, a primului-ministru sau a președintelui Consiliului Superior al Magistraturii;

f) veghează la respectarea procedurii pentru alegerea Președintelui României și confirmă rezultatele sufragiului;

g) constată existența împrejurărilor care justifică interimatul în exercitarea funcției de Președinte al României și comunică cele constatate Parlamentului și Guvernului; României;

h) dă aviz consultativ pentru propunerea de suspendare din funcție a Președintelui

i) veghează la respectarea procedurii pentru organizarea și desfășurarea referendumului și confirmă rezultatele acestuia; cetățeni;

j) verifică îndeplinirea condițiilor pentru exercitarea inițiativei legislative de către 
k) hotărăște asupra contestațiilor care au ca obiect constituționalitatea unui partid politic;

I) îndeplinește și alte atribuții prevăzute de legea organică a Curții.

Actele emise de această autoritate sunt deciziile, hotărârile și avizele. Deciziile și hotărârile Curții Constituționale sunt general obligatorii și au putere numai pentru viitor, iar avizul emis în situația existenței unei propuneri de suspendare din funcție a Președintelui României este singurul act al Curții care are un caracter consultativ. Fără îndoială că, în activitatea sa, Curtea Constituțională emite anumite acte a căror natură administrativă este certă. Așa sunt de pildă cele de organizare și funcționare a Curții, prevăzute în cuprinsul art. 4 din Anexa I a Hotărârii Plenului Curții Constituționale nr. 6/2012 pentru adoptarea Regulamentul de organizare și funcționare ${ }^{29}$.

Probleme pun însă actele adoptate în exercitarea atribuțiilor enumerate de art. 146 lit. a) - j) din Constituție. Considerăm că majoritatea hotărârilor și deciziilor pronunțate de Curtea Constituțională în exercitarea atribuțiilor enunțate nu ar putea fi atașate sferei actelor jurisdicționale, având în vedere că nu întrunesc elementele constitutive ale acestui tip de act. Astfel, actele prin care se pronunță asupra constituționalității legilor, inițiativelor de revizuire a Constituției, tratatelor sau altor acorduri internaționale ori regulamentelor Parlamentului, nu presupun judecarea unei stări de fapt prin aplicarea regulilor de drept incidente. Rolul Curții Constituționale este de a verifica dacă actele menționate sunt conforme cu prevederile Constituției, prin apelare la funcția de interpretare, fără ca însă să aibă de a face cu spețe concrete.

Or, noi credem că existența unui caz practic, particular a cărui soluționare se face prin aplicarea dreptului este chiar nota distinctivă a actelor jurisdicționale. Acesta este motivul pentru care avem rezerve față de opinia conform căreia deciziile prin care Curtea Constituțională apreciază asupra conformității unui act normativ cu actul suprem ar avea un caracter jurisdicțional. Contrar afirmațiilor unui autor ${ }^{30}$, considerăm că legea nu poate fi asimilată unei stări concrete de fapt, unei spețe particulare, având în vedere caracterul general și abstract al acesteia. Interpretarea dublă, în scopul de a verifica dacă sensul legii se subordonează înțelesului și rigorilor constituționale nu echivalează cu soluționarea unei situații de fapt determinate.

Ipoteza susceptibilă de controverse ar putea fi cea în care instanța de contencios constituțional se pronunță cu privire la o excepție de neconstituționalitate. Apreciem că deși sesizarea Curții cu o astfel de excepție poate avea loc doar în cadrul unui litigiu, trebuie avută în vedere natura hotărârii de verificare a conformității unui text de lege cu normele constituționale, fără a emite vreo judecată cu privire la litigiul din fața instanței de judecată. Astfel, Curtea Constituțională nu poate să indice în cuprinsul deciziei sale modul concret în care vor fi soluționate litigiile aflate pe rolul instanțelor de judecată în care a fost invocat temeiul de drept supus analizei și nici nu are competența de a completa un eventual vid legislativ. Un argument în acest sens este și faptul că deciziile Curții Constituționale prin care s-a constatat neconstituționalitatea unor legi sau ordonanțe ori a unor dispoziții din acestea sunt general obligatorii și nu sunt limitate doar la părțile din procesul în cadrul căruia a fost ridicată excepția. 
În ceea ce privește situația în care instanța constituțională soluționează un conflict juridic de natură constituțională între autoritățile publice amintim că, de principiu, prin aceste decizii instanța de contencios constituțional interpretează in concreto textul constituțional care a dat naștere conflictului juridic. În decizia nr. 53/2005 ${ }^{31}$, Curtea Constituțională a definit conflictul juridic de natură constituțională între autorități publice ca acte sau acțiuni concrete prin care o autoritate sau mai multe își arogă puteri, atribuții sau competențe, care, potrivit Constituției, aparțin altor autorități publice, ori omisiunea unor autorități publice, constând în declinarea competenței sau în refuzul de a îndeplini anumite acte care intră în obligațiile lor.

Constatând că prin intermediul acestor decizii este analizată o situație de fapt determinată și este soluționată prin aplicarea concretă a normelor constituționale incidente, natura lor este una jurisdicțională. De exemplu, prin decizia nr. 98/2008 ${ }^{32}$, Curtea a constatat și a soluționat un conflict juridic de natură constituțională între Guvern și Președintele României, în legătură cu refuzul Președintelui de a accepta propunerea Primului-ministru de numire a unei persoane în funcția de ministru. Ca urmare a judecării cauzei, instanța constituțională a dispus că Președintele poate refuza o singură dată, motivat, propunerea Primului-ministru.

Având în vedere că, în temeiul art. 147 alin. 4 din Constituție, deciziile Curții Constituționale sunt general obligatorii, autoritățile implicate în conflict trebuie să se supună deciziei Curții, mai exact interpretării pe care aceasta o dă textului constituțional. Astfel, se observă că, formal, Curtea nu obligă autoritățile la o acțiune sau inacțiune, ci, prin forța interpretării date textului constituțional, autoritățile publice implicate ị̦̂i vor vedea impusă o conduită corespunzătoare. Întrucât aceste decizii se disting de cele expuse anterior prin prisma faptului că se raportează la cazuri particulare pe care le rezolvă, opinăm în sensul că ele pot fi integrate în categoria actelor jurisdicționale.

Pentru aceleași argumente, toate actele prin care Curtea Constituțională soluționează contestații (de exemplu, cu privire la alegerea Președintelui României sau anularea alegerilor prezidențiale, constituționalitatea unui partid politic sau procedura pentru organizarea și desfășurarea referendumului) îndeplinesc cerințele unor acte jurisdicționale. În exercitarea acestor atribuții, Curtea este învestită cu un incident concret pe care trebuie să îl soluționeze prin transpunerea regulilor de drept constituționale la starea de fapt determinată.

Situația ar părea asemănătoare la o analiză de suprafață a cazului emiterii avizului consultativ la propunerea de suspendare din funcție a Președintelui României deoarece și în această ipoteză se analizează dacă faptele concrete sunt suficient de grave pentru a justifica o asemenea măsură. În realitate, nu ne aflăm în prezența unui act jurisdicțional, nefiind îndeplinită condiția soluționării cauzei prin emiterea unui act de putere publică. Curtea nu are competența de a hotărî, ea însăși, suspendarea președintelui, Parlamentul fiind autoritatea învestită cu prerogativa aplicării acestei sancțiuni.

Referitor la atribuțiile conferite de art. 146 lit. f), g), i) și j), majoritatea hotărârilor și deciziilor au caracter non jurisdicțional, cu excepția ipotezelor în care sunt soluționate contestații. În prima categorie intră, de pildă, hotărârile de stabilire și aducere la cunoștința publică a rezultatelor alegerilor prezidențiale, de validare a rezultatului alegerilor prezidențiale, de confirmare a rezultatului referendumului, de constatare a îndeplinirii condițiilor pentru exercitarea inițiativei legislative de către cetățeni. Nu ne propunem o abordare exhaustivă a 
acestui subiect, ci ne rezumăm la a sublinia că, atâta timp cât instanța nu își exercită prerogativa jurisdictio, actul adoptat nu este unul jurisdicțional. Nu contestăm forța juridică a acestor acte, dat fiind faptul că ele sunt emise în exercitarea unei atribuții constituționale, exclusive a unei autorități specializate, însă considerăm că acest aspect nu influențează natura lor non-jurisdicțională.

Ca o concluzie preliminară, arătăm că puterea publică nu aparține doar administrației publice, ci se regăsește și la celelalte autorități publice din cadrul celor trei puteri ale statului, care sunt nevoite să emită uneori acte administrative pentru a-și aduce la îndeplinire misiunile pe care le au în societate. Sfera actelor administrative este mult mai generoasă decât cea a actelor administrației, iar din categoria primelor am arătat că fac parte și anumite acte ale organelor judiciare. Mai mult, părerea noastră este că în activitatea de justiție majoritatea actelor nu sunt jurisdicționale, ci sunt acte administrative emise de organele judiciare. Acestea beneficiază de anumite denumiri specifice în virtutea faptului că sunt emise de organe speciale și intervin în procesul de judecată.

Criteriul de distincție dintre actele jurisdicționale și cele administrative este astfel cuprins în act, fiind strâns legat de cauza acestuia. Prin urmare, chestiunea se reduce în fond la a determina dacă, prin intermediul respectivului act, s-a spus sau nu dreptul. Am demonstrat așadar că organul jurisdicțional emite doar cu titlu de excepție acte de judecată, atunci când își îndeplinește misiunea de rostire a dreptului, iar majoritatea actelor efectuate cu alt scop rămân administrative. Situația se prezintă în mod similar cazului organelor administrației publice, ale căror acte de jurisdicție sunt rara avis.

\section{b. Actul notarial}

În doctrină s-a mai pus problema naturii juridice a actelor notarului public. în reglementarea actuală, biroul notarial se înfățișează ca o instituție de drept privat, iar nu ca un organ al administrației de stat. El are un caracter autonom, independent față de toate celelalte autorități publice. Această autonomie rezultă, în termeni neechivoci, din dispozițiile Legii nr. 36/1995 33 . Potrivit art. 3 din Legea nr. 36/1995, notarul public este învestit să îndeplinească un serviciu de interes public și are statutul unei funcții autonome. Este fără îndoială că activitatea desfășurată de biroul notarial este una de autoritate publică, însă această caracteristică nu explică natura juridică a actelor sale, fiind necesar în plus să determinăm dacă îndeletnicirea este una administrativă sau una jurisdicțională.

Trebuie precizat că activitatea notarială este una esențialmente necontencioasă, acest caracter fiind recunoscut, chiar și procedurii succesorale notariale. Cu toate acestea, după cum am arătat și cu ocazia analizei hotărârilor judecătorești pronunțate în cadrul unei proceduri necontencioase, includerea unui act în categoria jurisdicțională nu este condiționată de existența unui litigiu. Astfel, faptul că toate actele și lucrările notariale se desfășoară într-o procedură grațioasă, în lipsa unui diferend, nu poate constitui un criteriu în funcție de care să realizăm calificarea juridică a acestora.

Referitor la aspectul menționat, a fost exprimată opinia potrivit căreia activitatea notarială nu are un caracter jurisdicțional, ci unul administrativ ${ }^{34}$. Această concluzie are la bază împrejurarea că notarul nu pronunță dreptul, ci aplică în mod tehnic normele legale în 
cadrul procedurii solicitate de părți, iar în ipoteza ivirii unui litigiu, le îndrumă pe acestea în fața organelor jurisdicționale competente. Un alt autor ${ }^{35}$ a concluzionat că biroul notarial se înfățișează ca o instituție de drept privat, iar nu ca un organ al administrației de stat, însă a arătat că actele notariale, sub aspectul conținutului lor au un caracter special, păstrând unele din caracteristicile actului administrativ întrucât sunt acte de autoritate. Teoria a fost și criticată, susținându-se că generează o stare de confuzie deoarece, dacă acceptăm că activitatea notarială nu are un caracter jurisdicțional, ci unul administrativ și că actele emise de notarul public păstrează unele din caracteristicile actului administrativ, atunci înseamnă că procedurile notariale și instituția notarului public, în cadrul cărora se emit asemenea acte, au un caracter administrativ ${ }^{36}$.

Privind lucrurile într-o altă lumină, un autor ${ }^{37}$ a argumentat că actele notarului public nu pot fi considerate acte administrative, din moment ce nu cuprind o manifestare de voință propriu-zisă a emitentului actului. Acestea sunt limitate la constatarea existenței voinței unor alte persoane sau a unei stări de fapt și nu dau naștere, prin ele însele, unor raporturi juridice. Bineînțeles că această împrejurare nu este de natură să înlăture semnificația juridică a actelor notariale, însă efectele lor nu sunt produse ca urmare a manifestării de voință a organului emitent.

Credem că pentru rezolvarea acestei controverse este utilă aplicarea metodei divide et impera deoarece nu poate fi exprimată o concluzie fundamentată doar prin analiza cu titlu general a actelor și lucrărilor notariale. Astfel, le vom împărți în trei categorii, în funcție de raportul lor cu un alt act privat. Înainte de toate însă, amintim distincția pe care am realizat-o anterior între acte administrative și acte ale administrației și subliniem că o eventuală calificare a actelor emise de notar ca fiind administrative nu atrage concluzia că notarul public ar fi un organ al administrației de stat. Din contră, așa cum deja am demonstrat, și alte autorități învestite cu putere publică au abilitatea de a emite acte administrative.

\section{Acte notariale net administrative}

Legea nr. 36/1995 a notarilor publici și a activității notariale, în cuprinsul art. 12, face distincție între diverse acte și lucrări notariale ${ }^{38}$. Analizând aceste prerogative, observăm că unele dintre ele se materializează prin acte care sunt efectiv ale notarului și pe care acesta le întocmește fără să aibă nevoie de participarea unui alt subiect. Există astfel în activitatea notarială anumite acte care sunt net administrative și se concretizează într-o manifestare de voință a notarului, fără a presupune și o altă voință. Intră în această categorie toate încheierile de legalizare sau de certificare de fapte.

$\mathrm{Cu}$ toate că actele menționate nu sunt efectuate din oficiu, fiind necesară o solicitare prealabilă a beneficiarului, acest aspect nu le modifică natura juridică, ele rămânând, din punct de vedere tehnic și volitiv, pure acte administrative. Situația este diferită față de actul de autentificare, în cazul căruia voința notarului, ca participant la perfectarea contractului de fond, se adaugă acordului de voințe al părților. În ipoteza de față, notarul este singurul autor al actului de legalizare a unei semnături, a unei copii de pe un înscris sau de certificare a unei fapte, nemaiavând calitatea de participant, respectiv de persoană prin intermediul căreia se încheie un alt act juridic al părților. 
Menționăm că activitatea notarului în exercitarea acestor atribuții nu se limitează nicidecum la constatarea unui aspect, ci acesta exprimă o voință în sensul emiterii actului. Dacă am considera altfel nu am putea explica modul în care actele notarului generează efecte juridice. Ținând cont de faptul că aceste tipuri de acte ale notarului nu sunt adiționale unui alt act de natură privată, constatăm că ele interferează în cea mai mică măsură cu sfera dreptului privat.

\section{Actele notarului care sunt grefate pe un act al părților}

Chestiunea care generează controverse este dacă actul notarului care este grefat pe un alt act al părților ar putea fi desprins de acesta din urmă și analizat separat. Cu titlu de exemplu, menționăm încheierea de autentificare a unui contract. în primul rând, este necesar să arătăm că atâta timp cât notarul public nu este parte la încheierea actului de fond pe care îl autentifică, efectele actului nu se produc niciodată față de acesta. Având în vedere că elementul definitoriu al calității de parte a unui act juridic este exclusiv de ordin subiectiv, fiind reprezentat de voința persoanei, nu putem include notarul în această categorie limitativă.

Simpla prezență fizică a notarului și faptul că el contribuie la perfectarea actului nu sunt elemente suficiente pentru a-i atribui calitatea de parte, motiv pentru care doctrina ia acordat apelativul de intervenient ${ }^{39}$. Prezența juridică a unei persoane la încheierea unui act juridic este reprezentată atât de cauza concretă, cât și de interesul propriu care justifică psihologic această cauză. Or, declarația notarului vizează doar înscrisul, și nu produce nicio consecință cu privire la actul juridic cuprins în înscris. Astfel, voința sa nu suplimentează raportul juridic născut din convenția părților cu noi efecte juridice, ci este manifestată doar pentru a asigura preconstituirea unei probe.

Persoana care își exprimă voința juridică devine creditor sau debitor al unei obligații, fiind prinsă în mrejele unor raporturi juridice pe care le-a vizat, în virtutea intenționalității juridice. Reflexivitatea conceptului de parte se remarcă prin aceea că efectele actului se produc doar în raport cu persoanele incluse în această categorie, respectiv autorii reflexivi ai actului civil. Prin urmare, elementul esențial pentru dobândirea calității de parte contractantă de către o persoană care participă la încheierea actului este răsfrângerea asupra sa a efectelor juridice ale intenției sale $e^{40}$.

În al doilea rând, autentificarea unui înscris notarial impune respectarea unei proceduri stricte, fiind necesară întrunirea elementelor descrise de art. 89 alin. 2 din Legea nr. 36/1995. Astfel, notarul public este dator să stabilească identitatea persoanelor prezente în fața sa, să verifice existența consimțământului la încheierea actului, să ateste semnătura părților și să consemneze data perfectării actului. Când toate aceste cerințe sunt îndeplinite, notarul exprimă o voință prin care autentifică înscrisul constatator al actului juridic dintre părți.

În al treilea rând, dacă nu am accepta posibilitatea separării acestor acte, am ajunge la anihilarea teoriei conversiunii actelor juridice. În acest caz, actul ar fi nul cu totul și nu ar mai avea ce să se convertească. Așa cum s-a arătat și în doctrina de specialitate ${ }^{41}$, normele juridice dedicate autentificării actelor din legislația notarială nu prevăd expres vreo sancțiune specială pentru nerespectarea cerințelor legale, astfel încât trebuie aplicat textul general, respectiv art. 86 alin. 1 din Legea nr. 36/1995, care sancționează cu 
nulitatea relativă încălcarea cerințelor menționate de art. 83 lit. a) - k) din lege. Sancțiunea intervine însă doar în cazul în care actele nu pot fi îndreptate și au produs părții o vătămare care nu poate fi înlăturată în alt mod decât prin desființarea actului.

Autorul a argumentat pertinent că sancțiunea nulității absolute ar trebui să intervină doar în ipotezele în care fie au lipsit, fie au fost îndeplinite greșit etapele structurale ale autentificării prevăzute de art. 89 alin. 2 . Din contră, dacă toate elementele au fost realizate, însă a fost omisă menționarea lor în încheierea de autentificare, atunci actul este supus îndreptării. Nulitatea relativă prevăzută de art. 98 din lege afectează încheierea în măsura în care nu se procedează la îndreptarea sau completarea lui.

Pe de altă parte, art. 271 alin. 1 C.pr.civ. sancționează cu nulitatea absolută înscrisul ce ar trebui să fie autentic, dar care este întocmit fără respectarea formelor prevăzute pentru încheierea sa valabilă ori de o persoană incompatibilă, necompetentă sau cu depășirea competenței. Achiesăm la opinia expusă de autorul citat conform căreia contradicția dintre cele două texte de lege este doar aparentă, având în vedere că art. 98 din Legea nr. 36/1995 penalizează lipsa mențiunilor obligatorii, iar art. 271 C.pr.civ. se referă la încălcarea formalităților de adoptare a actului.

Din acest motiv a prevăzut legiuitorul în cuprinsul art. 271 alin. 2 C.pr.civ. posibilitatea conversiunii actului, stabilind că înscrisul prevăzut la alin. 1 face deplină dovadă ca înscris sub semnătură privată, dacă este semnat de părți, iar dacă nu este semnat, constituie, între acestea, doar un început de dovadă scrisă. Așadar, chiar dacă manifestarea de voință a notarului public este înlăturată întrucât acesta fie nu a respectat formele impuse de lege, fie era incompatibil ori necompetent, este permisă totuși valorificarea voinței părților. Credem că acest argument susține opinia noastră în sensul că încheierea de autentificare reprezintă un act distinct, care poate fi desprins de actul de fond cu care face corp comun.

Față de aceste argumente, considerăm că simbioza dintre actul notarului și actul părților poate fi întotdeauna destrămată. În ceea ce privește natura juridică a încheierii, opinăm în sensul includerii acesteia în categoria actelor administrative. Avem în vedere în acest sens că încheierea de autentificare emisă de notarul public nu se rezumă la constatarea consimțământului și a aspectelor faptice, ci cuprinde și declarația de autentificare. Această declarație produce, la rândul său, anumite efecte juridice specifice care se disting de efectele actului juridic civil încheiat între părți, motiv pentru care constituie un act aparte.

Mai mult, în materia actelor supuse încheierii în formă autentică ad validitatem, efectele acestora chiar sunt condiționate de existența acestei solemnități. Înscrisul autentic este definit de art. 269 C.pr.civ. conform căruia acesta este reprezentat de înscrisul întocmit sau, după caz, primit și autentificat de o autoritate publică, de notarul public sau de către o altă persoană învestită de stat cu autoritate publică, în forma și condițiile stabilite de lege. Așadar, elementul esențial al actului autentic îl constituie prezența unui agent instrumentator învestit cu autoritate publică în momentul perfectării actului, precum și implicarea acestuia în elaborarea sa.

Un exemplu edificator este situația contractului de vânzare a unui bun imobil care, în lipsa autentificării notariale, nu este apt să genereze efectele specifice contractului pe care îl vizează părțile. În lipsa adăugării declarației notarului public peste acordul de voințe al părților, actul în discuție ar putea să aibă cel mult valoarea unui antecontract, în ipoteza 
aplicării conversiunii. Prin urmare, putem să conchidem că aceste încheieri notariale sunt tot acte administrative, care se detașează de actul civil, chiar dacă sunt emise de un subiect care nu ține nici de puterea executivă a statului, nici de cea jurisdicțională.

\section{Încheierile finale în procedura succesorală}

Probabil cel mai complex act al notarului public, încheierea finală emisă în procedura succesorală este și punctul culminant al acestei proceduri, prin care se concluzionează toate cercetările efectuate și probele administrate, precum și acordul succesibililor în cauza succesorală dezbătută. Din acest motiv, natura juridică a actului suscită anumite observații.

Spre deosebire de ipoteza încheierii de autentificare grefată pe un alt act amintită anterior, în cazul căreia notarul este un simplu intervenient, calitatea acestuia în procedura succesorală se apropie mai degrabă de cea a unei părți. Cu toate că efectele actului nu îl vizează, rolul notarului nu se mai rezumă de această dată la cel al unui agent instrumentator. Prin actul emis la încheierea procedurii, notarul „tranșează” cauza succesorală din punct de vedere notarial, în sensul că stabilește moștenitorii, determină cotele și masa succesorală și atestă modalitatea de împărțire a bunurilor, dacă este cazul.

Având în vedere că emiterea unei asemenea încheieri este condiționată de acordul tuturor succesibililor, considerăm că natura sa juridică este una contractuală. Totodată, manifestarea de voință a notarului este înglobată și ea în conținutul acestui act și nu poate fi delimitată de actul părților precum în cazul autentificării unui contract. Deci, toate voințele persoanelor implicate în procedura succesorală notarială se intersectează în acest act complex.

În cadrul procedurii succesorale notariale reglementată de prevederile art. 101 118 din Legea nr. 36/1995 și art. 233 - 259 din Regulamentul pentru punerea în aplicare a Legii notarilor publici și a activității notariale ${ }^{42}$, notarul public administrează la cererea părților sau din oficiu, probele necesare pentru stabilirea corectă a stării de fapt și de drept, respectiv masa succesorală, persoanele care au calitatea de moștenitori și cotele ce li se cuvin, analizând înscrisurile, declarațiile moștenitorilor care se consemnează în încheierile de dezbateri și în încheierea finală, declarațiile martorilor, iar după administrarea tuturor probelor întocmește încheierea finală pe baza căreia se eliberează certificatul de moștenitor .

Astfel, procedura succesorală notarială se aseamănă cu o procedură necontencioasă desfășurată în fața instanței de judecată, iar notarul devine practic un judecător care soluționează situația prezentată în fața sa, prin aplicarea concretă a normelor juridice incidente. Acesta este și motivul pentru care legiuitorul a recunoscut certificatului de moștenitor natura juridică și puterea doveditoare a unui titlu de proprietate, la fel ca în cazul hotărârii judecătorești. Potrivit prevederilor art. 1133 alin. 1 C.civ. certificatul de moștenitor face dovada calității de moștenitor, legal sau testamentar, precum și dovada dreptului de proprietate al moștenitorilor acceptanți asupra bunurilor din masa succesorală, în cota care se cuvine fiecăruia.

Faptul că notarul public desfășoară o activitate jurisdicțională necontencioasă în cadrul procedurii succesorale notariale, pronunțând adevărate soluții pe baza probelor prezentate de părți sau dispuse din oficiu este demonstrat și de împrejurarea că acesta are 
statutul unei funcții autonome, ceea ce presupune independență față de orice autoritate sau persoană, notarul fiind obligat să se supună numai legii în îndeplinirea sarcinilor profesionale. În cadrul procedurii succesorale notarul public soluționează speța, prin aplicarea normelor de drept incidente la situația de fapt pe care o reține, întocmai ca în situația în care judecătorul este învestit cu dezbaterea unei succesiuni, fapt pentru care apreciem că actul final emis în această procedură are caracter jurisdicțional.

În privința naturii juridice a certificatului de moștenitor, având în vedere că acesta nu este altceva decât un extras din încheierea finală întocmită în procedura succesorală, acesta reprezintă un act administrativ. Așadar, cu toate că la prima vedere lucrurile par amestecate, la o privire atentă pot fi deslușite diferențele, care nu sunt de lepădat. Am observat că instituția notarului public este una complexă deoarece, deși nu face parte din organele administrației publice, majoritatea actelor și lucrărilor emise de un notar pot fi incluse în categoria vastă a actelor administrative. Totodată, nu putem să pierdem din vedere că unul dintre cele mai importante acte notariale, respectiv încheierea finală din procedura succesorală, are caracter jurisdicțional, cu toate că notarul nu este un veritabil organ de jurisdicție.

În lumina celor expuse, conchidem că și notarul public emite în activitatea pe care o desfășoară numeroase acte administrative, fără ca acest aspect să presupună că notarul public s-ar încadra în categoria autorităților administrației publice.

\section{c. Acte administrative care conțin drepturi civile}

Pe de altă parte, mai menționăm că există acte administrative care conțin în cuprinsul lor drepturile civile, cum ar fi, de pildă, titlurile de proprietate. În această ipoteză nu se mai poate face distincția menționată anterior cu ocazia analizei actelor notarului grefate pe un act al părților, în sensul că nu se mai evidențiază o detașare a actului administrativ de cel civil. Titlul nu se mai suprapune pe altceva, ci este asimilat cu actul autentic, care constituie proba în sine a dreptului și a constituirii sale.

Lucrurile se prezintă în aceeași manieră și în ceea ce privește actele de stare civilă care se întemeiază pe acte juridice, neputând fi făcută o diferențiere între voința civilă și forma administrativă care o îmbracă. Tradițional, în doctrina de specialitate s-a susținut ideea că actele de stare civilă au o natură juridică complexă, care ar trebui analizată atât din punct de vedere al dreptului civil, cât și al dreptului administrativ ${ }^{43}$. Din perspectivă civilistă, actele de stare civilă sunt privite ca acte autentice, în timp ce viziunea administrativă le tratează ca înscrisuri doveditoare ale actelor administrative întocmite cu ocazia înregistrărilor de stare civilă.

Teza contrară se sprijină pe ideea că acestor înscrisuri le lipsește o condiție pentru a fi considerate acte juridice, respectiv manifestarea de voință a funcționarilor de stare civilă ${ }^{44}$. Astfel, s-a apreciat că din moment ce înregistrarea actelor și faptelor de stare civilă și înscrierea mențiunilor se fac la cerere, pe baza declarației persoanei obligate la aceasta, sau din oficiu, în condițiile prevăzute de lege, ofițerul de stare civilă, întocmind un act de stare civilă, nu face altceva decât să execute o operațiune de înregistrare a unui act juridic sau a unui fapt de stare civilă. Acesta nu are libertatea de a-și manifesta voința în acest sens ori în legătură cu conținutul actului. 
Considerăm că această susținere este viciată deoarece nu are în vedere complexitatea generării unui act de putere publică. Noțiunea de manifestare de voință nu trebuie redusă la înțelesul său restrâns din dreptul civil. În domeniul administrativ aceasta se întemeiază, în primul rând, pe puterea publică acordată de legiuitor în vederea satisfacerii unui interes general. Așadar, atunci când emite un act, persoana învestită cu această putere nu exteriorizează o voință personală și nu urmărește un interes propriu, ci exprimă voința generală.

Dovadă în acest sens, în materie de stare civilă, stau dispozițiile art. 1 teza II din Legea nr. 119/1996 ${ }^{45}$, conform cărora actele de stare civilă se întocmesc în interesul statului și al persoanei și servesc la cunoașterea numărului și structurii populației, a situației demografice, la apărarea drepturilor și libertăților fundamentale ale cetățenilor. La fel cum am arătat anterior că notarul public îndeplinește un serviciu de interes general, exprimând o voință pentru emiterea actului, și actul întocmit de ofițerul de stare civilă este caracterizat de o manifestare de voință. Un argument suplimentar îl constituie prevederile art. 6 alin. 2 din Legea nr. 119/1996 care instituie obligația semnării actului de stare civilă atât de ofițerul de stare civilă, cât și de declarant.

Pe de altă parte, natura juridică a actelor de stare civile întemeiate pe acte juridice nu se poate reduce la caracteristica lor de a fi înscrisuri autentice, ci ele înglobează în conținutul lor chiar drepturile, obligațiile și îndatoririle civile care derivă din situația civilă pe care o atestă. Astfel, actul de căsătorie nu este un simplu înscris ad probationem al căsătoriei prin care se dovedește consimțământul soților. Acesta este chiar actul juridic unilateral statutar, reprezentat de voința concordantă a soților, peste care se suprapune manifestarea voinței generale exprimată de ofițerul de stare civilă. Așa fiind, actul nu se rezumă la a constata voința părților, ci o include în cuprinsul său, căsătoria neputând să fie valabilă în alt mod.

Voința exprimată a persoanelor implicate nu valorează nimic juridic dacă nu este înglobată într-un act încheiat prin intermediul ofițerului de stare civilă învestit de lege cu putere publică. Aceasta este singura modalitate prin care se pot genera raporturile juridice specifice căsătoriei. La fel, recunoașterea de paternitate făcută prin act autentic sau constatată prin hotărâre judecătorească, atâta timp cât nu este făcută mențiunea în cuprinsul actului de stare civilă, nu poate să producă niciun efect juridic. Considerăm că este eronată concepția potrivit căreia actele de stare civilă ar avea un rol exclusiv probatoriu, menirea aceasta restrânsă revenind certificatelor de stare civilă eliberate pe baza lor. În schimb, actele de stare civilă au o natură complexă, fiind acte administrative care conțin în cuprinsul lor chiar drepturile civile.

\section{Concluzie}

În lumina celor expuse, concluzionăm în sensul că distincția actului administrativ de alte acte emise în regim de putere publică nu poate avea ca punct de pornire calitatea subiectului de drept care emite actul. Deși autoritățile învestite, în principal, cu puterea de a emite, în mod unilateral, acte administrative cu caracter obligatoriu și executoriu sunt cele ale administrației, am arătat că acestea nu sunt singurele organe care dețin prerogativa emiterii unor asemenea acte. Puterea publică nu este un atribut exclusiv al administrației, ci este specifică tuturor autorităților publice din sfera celor trei puteri de stat. Așadar, având 
în vedere numeroșii subiecți de drept care pot emite acte administrative, am evidențiat că sintagmele acte administrative și acte de administrație nu sunt sinonime, acestea din urmă fiind incluse în mulțimea mai extinsă a primelor.

Totodată, din analiza actelor emise de autoritățile puterii judecătorești a rezultat că o mare parte dintre acestea sunt acte non-jurisdicționale, respectiv acte administrative întocmite în regim de putere, însă menite să creeze cadrul necesar pentru realizarea dreptului. Astfel, actele jurisdicționale sunt cele prin care se tranșează o problemă de drept cu privire la o stare de fapt concretă. În același sens, majoritatea actelor și lucrărilor notarului public sunt acte administrative, iar încheierile finale din procedura succesorală sunt acte jurisdicționale deoarece notarul soluționează problema succesorală.

Actul administrativ nu poate fi definit însă nici de procedura reglementată de legiuitor pentru contestarea sa. Astfel, faptul că unora dintre actele analizate de noi și incluse în categoria largă a actelor administrative nu le este aplicabilă integral procedura de contencios administrativ, nu înseamnă în mod automat că acestea ar avea o altă natură juridică. După cum, nici aserțiunea că unele acte sunt supuse controlului pe calea contenciosului administrativ nu atrage concluzia că doar acestea ar fi acte administrative, consumând toată mulțimea lor. Amintim în acest sens că însuși legiuitorul exclude anumite acte de la acest tip de control, pe când altele sunt supuse unor proceduri speciale, prevăzute în alte acte normative. Este cazul, de pildă, al proceselor verbale de constatare și sancționare a contravențiilor ${ }^{46}$ și al litigiilor de fond funciar ${ }^{47}$.

În funcție de specificul lor, care le divide în mai multe subcategorii, actele individuale de putere publică beneficiază de proceduri distincte în privința verificării legalității și temeiniciei. Remediul pe care legiuitorul alege să îl pună la îndemâna celui slab nu poate să schimbe caracteristicile actului. În susținerea acestei teze, menționăm că, deși în prezent toate litigiile generate de contracte administrative sunt de competența instanței de contencios administrativ, anumite reglementări speciale din trecut au stabilit competența instanței de drept comun în soluționarea pricinilor referitoare la anumite contracte administrative determinate ${ }^{48}$.

Pe cale de consecință, criteriul la care trebuie să ne raportăm pentru o corectă delimitare credem că se subsumează formei de activitate care se aduce la îndeplinire prin intermediul acestuia. Prin urmare, dacă actul emis are ca scop principal realizarea unei activități executive (de organizare și asigurare a aplicării legii), atunci acesta este înglobat în sfera actelor administrative. În sens contrar, dacă forma fundamentală de activitate realizată prin emiterea actului este una jurisdicțională (în sensul de rostire a dreptului) ne aflăm în prezența unui act jurisdicțional.

\footnotetext{
* Doctorand, Facultatea de Drept UBB Cluj-Napoca; judecător, Judecătoria Alba-Iulia; oanagligan@yahoo.com.

${ }^{1}$ G. Guțu - Dicționar latin-român, ed. Științifică și Enciclopedică, București 1983, p. 38

${ }^{2}$ A. Iorgovan - Tratat de drept administrativ, vol. I, ed. All Beck, București, 2001, p. 70
} 
${ }^{3}$ A. Iorgovan - Drept administrativ, vol. I, ed. Hercules, București, 1993, p. 28

${ }^{4}$ Publicată în Monitorul Oficial al României nr. 1154 din data de 07.12.2004

${ }^{5}$ T. Drăganu - Actele administrative și faptele asimilate lor supuse controlului judecătoresc potrivit Legii nr. 1/1967, ed. Dacia, Cluj Napoca, 1970, p. 72. Notă: Lucrarea citată are temei în Constituția din anul 1965 și se referă la organele administrației, așa cu erau ele reglementate de acest act normativ. Menționăm că, din opera acestui reputat autor, am avut în vedere conceptele dezvoltate cu măiestrie, respectiv raționamentele, criteriile și exemplele, pe care le-am translatat și adaptat la instituțiile juridice contemporane. Interpretarea noastră este una dialectică, iar în cadrul analizei noastre am luat în considerare modificarea structurii constituționale.

${ }^{6}$ D. Cimpoeru - Actele jurisdicționale ale Curții Constituționale, ed. Wolters Kluwer, București, 2009, p. 19

${ }^{7}$ O. Podaru - Drept administrativ. Vol. I. Actul administrativ. Repere pentru o teorie altfel, ed. Hamangiu, București, 2010, p. 42

${ }^{8} \mathrm{Cu}$ titlu de exemplu, amintim dispozițiile art. 7 din Regulamentul de ordine interioară al instanțelor judecătorești, cuprins în Anexa la Hotărârea Plenului Consiliului Superior al Magistraturii nr. 1375 din 17 decembrie 2015 care enumeră atribuțiile președintelui Curții de Apel

${ }^{9}$ V.M. Ciobanu, T.C. Briciu, C.C. Dinu - Drept procesual civil. Drept execuțional. Arbitraj. Drept notarial, ed. Național, București, 2013, p. 229

${ }^{10}$ E. Heroveanu - Principiile procedurei judiciare, ed. Institutul de Arte Grafice „Lupta” N. Stroilă, București, 1932, p. 76-77 și 176

${ }^{11}$ V.M. Ciobanu, T.C. Briciu, C.C. Dinu - Drept procesual civil. Drept execuțional. Arbitraj. Drept notarial, ed. Național, București, 2013, p. 229-230

12 J. M. Denieuil - Petite traite de l'ecrit judiciare, Paris, 2007, p. 178 și urm., apud G. Mateuț - Tratat de procedură penală, Partea generală, vol. II, ed. C.H. Beck, București, 2012, p. 745

${ }_{13}^{13}$ V.M. Ciobanu - Tratat teoretic și practic de procedură civilă, ed. Național, București, 1996, p. 27-31

${ }^{14}$ I. Stoenescu, S. Zilberstein - Drept procesual civil. Teoria generală, ed. Didactică și Pedagogică, București, 1983, p. 248

${ }^{15}$ D. Cimpoeru - Actul jurisdicțional - delimitări conceptuale, Revista de Drept Public nr. 1/2007, ed. C. H. Beck, p. 61

${ }^{16}$ V.M. Ciobanu - Tratat teoretic și practic de procedură civilă, ed. Național, București, 1996, p. 27-31

${ }^{17}$ I. Deleanu - Instituții și proceduri constituționale, ed. Servo-Sat, Arad, 2003, p. 657-662

${ }^{18}$ G. Boroi, D. Rădescu - Codul de procedură civilă comentat și adnotat, ed. All Beck, București, 1994, p. 356-359

${ }^{19}$ G. Couchez - Procedure civile, ed. Sirey, Paris, 1994, p. 153

20 O. Ungureanu - Actele de procedură în procesul civil (La instanța de fond), ediția a III-a, ed. Lumina Lex, București, 2000, p. 27

${ }^{21} \mathrm{G}$. Boroi - Codul de procedură civilă comentat și adnotat, vol. I, ed. All Beck, București, 2001, p. 452

22 V.M. Ciobanu, T.C. Briciu, C.C. Dinu - Drept procesual civil. Drept execuțional. Arbitraj. Drept notarial, ed. Național, București, 2013, p. 331

${ }^{23}$ V.M. Ciobanu, T.C. Briciu, C.C. Dinu - Drept procesual civil. Drept execuțional. Arbitraj. Drept notarial, ed. Național, București, 2013, p. 31

${ }^{24}$ V. M. Ciobanu, G. Boroi, T. C. Briciu - Drept procesual civil, ed. C. H. Beck, 2011, p. 326

${ }^{25}$ M. Tăbârcă - Drept procesual civil, vol. II, ed. Universul Juridic, 2013, p. 475

${ }^{26}$ G. Boroi - Codul de procedură civilă comentat și adnotat, vol. I, ed. All Beck, București, 2001, p. 434 
${ }^{27}$ M. Tăbârcă - Drept procesual civil, vol. II, ed. Universul Juridic, 2013, p. 504

${ }^{28}$ T. Drăganu - Drept constituțional și instituții politice, ed. Lumina Lex, Cluj-Napoca, 1998, p. 307; I. Muraru, M. Constantinescu - Curtea Constituțională a României, ed. Albatros, București, 1997, p. 43

${ }^{29}$ Publicată în Monitorul Oficial al României nr. 198 din data de 27.03.2012

${ }^{30}$ D. Cimpoeru - Actele jurisdicționale ale Curții Constituționale, ed. Wolters Kluwer, București, 2009, p. 73

${ }^{31}$ Publicată în Monitorul Oficial al României nr. 144 din data de 17.02.2005

32 Publicată în Monitorul Oficial al României nr. 140 din data de 22.02.2008

${ }^{33}$ Republicată în Monitorul Oficial al României nr. 444 din data de 18.06.2014

${ }^{34} \mathrm{M}$. Mihail - Unele considerații privind natura juridică a activității notariale, Buletinul Notarilor Publici nr. 1/1996, p. 19 apud G. Dobrican - Natura juridică a procedurilor notariale și a instituției notarului public, Revista Dreptul nr. 4/2001

${ }^{35}$ I. Leș - Organizarea sistemului judiciar, a avocatului și a activității notariale, ed. Lumina Lex, București, 1997, p. 235, 239 apud G. Dobrican - Natura juridică a procedurilor notariale și a instituției notarului public, Revista Dreptul nr. 4/2001

${ }^{36} \mathrm{G}$. Dobrican - Natura juridică a procedurilor notariale și a instituției notarului public, Revista Dreptul nr. $4 / 2001$

${ }^{37}$ T. Drăganu - Actele administrative și faptele asimilate lor supuse controlului judecătoresc potrivit Legii nr. 1/1967, ed. Dacia, Cluj Napoca, 1970, p. 89-90

${ }^{38}$ Notarul public îndeplinește următoarele acte și proceduri notariale:

a) redactarea înscrisurilor cu conținut juridic, la solicitarea părților;

b) autentificarea înscrisurilor;

c) procedura succesorală notarială;

d) certificarea unor fapte, în cazurile prevăzute de lege;

e) legalizarea semnăturilor de pe înscrisuri, a specimenelor de semnătură, precum și a sigiliilor;

f) darea de dată certă înscrisurilor;

g) primirea în depozit a bunurilor, a înscrisurilor și a documentelor prezentate de părți, precum și a sumelor de bani, a altor bunuri, înscrisuri sau documente găsite cu ocazia inventarului succesoral, în limita spațiului și utilităților de care dispune biroul notarial;

h) actele de protest al cambiilor, al biletelor la ordin și al cecurilor;

i) legalizarea copiilor de pe înscrisuri;

j) efectuarea și legalizarea traducerilor;

k) eliberarea de duplicate de pe actele pe care le-a întocmit;

I) activități fiduciare, în condițiile legii;

m) numirea, în cazurile prevăzute de lege, a custodelui sau a curatorului special;

n) înregistrarea și păstrarea, în condițiile legii, a amprentelor dispozitivelor speciale de marcat;

o) certificarea etapelor procedurale ale licitațiilor și/sau ale rezultatelor acestora;

p) procedura divorțului, în condițiile legii;

$\mathrm{p}^{1}$ ) emiterea certificatului european de moștenitor;

q) lichidarea pasivului succesoral, cu acordul tuturor moștenitorilor;

$q^{1}$ ) emiterea titlurilor executorii notariale;

r) orice alte operațiuni prevăzute de lege.

${ }^{39}$ P. Vasilescu - Drept civil. Obligații, ed. Hamangiu, București, 2012, p. 464

${ }^{40}$ P. Vasilescu - Drept civil. Obligații, ed. Hamangiu, București, 2012, p. 464 
${ }^{41}$ I. F. Popa - Forma autentică în contracte - abordarea Codului Civil în 5 ani de Cod Civil: perspectiva notarială, ed. Monitorul Oficial, București, 2016, p. 151

${ }^{42}$ Aprobat prin Ordinul Ministerului Justiției nr. 2333/C/2013, publicat în Monitorul Oficial al României nr. 479 din data de 01.08 .2013

${ }^{43}$ O. Ungureanu, C. Munteanu - Drept civil. Persoanele în reglementarea noului Cod civil, ediția a 3-a, ed. Hamangiu, 2015, p. 307

${ }^{44} \mathrm{~T}$. Drăganu - Actele administrative și faptele asimilate lor supuse controlului judecătoresc potrivit Legii nr. 1/1967, ed. Dacia, Cluj Napoca, 1970, p. 92-94. Notă: Menționăm că viziunea exprimată de autor se referă la organizarea Notariatului de Stat

${ }^{45}$ Republicată în Monitorul Oficial al României nr. 339 din data de 18.05.2012

${ }^{46}$ O.G. nr. 2/2001 privind regimul juridic al contravențiilor, publicată în Monitorul Oficial al României nr. 410 din data de 25.07.2001

${ }^{47}$ Legea nr. 18/1991 a fondului funciar, republicată în Monitorul Oficial al României nr. 1 din data de 05.01.1998

${ }^{48}$ De exemplu, art. 286 alin. 1 din O.U.G. nr. 34/2006 (publicată în Monitorul Oficial al României nr. 418 din data de 15.05.2006), înainte de modificarea adusă prin art. I pct. 68 din O.U.G. nr. 77/2012 (publicată în Monitorul Oficial al României nr. 827 din data de 10.12.2012), stabilea că toate aceste litigii sunt de competența secției comerciale a tribunalului în raza teritorială a căruia își are sediul autoritatea contractantă. 